\title{
Examination of Self-efficacy and Self-esteem Levels of Sports Club Members in Terms of Membership History and Gender
}

\section{Zarife Taştan*, Turhan Toros, Rabia Yıldız Öztürk}

Department of Sports Sciences, Mersin University, Mersin, Turkey

Study Area: Mersin, Turkey

Coordinates: $36^{\circ} 48^{\prime} \mathrm{N} ; 34^{\circ} 38^{\prime} \mathrm{E}$

Keywords: Physical Performance, Federation

\section{Abstract}

This is a quantitative and relational screening model designed to determine the relationship between selfesteem and self-efficacy levels of sports club members. The easily available sampling method was used in the sample selection. The sample of the study consists of 246 participants who were the members of the sports club in the Mediterranean region. "Stanley Coopersmith Self-Esteem Scale" and "Self-Efficacy Scale" were used to collect data from participants in the study. In addition, the personal information form was used to determine the demographic information of the participants. When the self-efficacy mean scores of sports club members were examined in terms of gender, no statistically significant difference was evidenced. When the mean scores of self-esteem and selfefficacy mean scores were examined in terms of the membership date, a statistically significant difference was evidenced for both the cases. In future studies, researchers should look at the different demographic characteristics of both women and men.

\section{Introduction:}

Today, there are many organizations working outside and independently of official institutions. These organizations are non-profit non-governmental organizations that lobby for their social, cultural, political, legal and environmental purposes, recruit their members and employees on a voluntary basis. Universally, sports clubs are one of the biggest organizations. All people in the world are different beings from each other. The most fundamental pattern that separates us existentially and makes us who we are, has been defined as the "self" by branches of science that study human behaviour. When the history of the studies about the self is examined, it is seen that the first serious and detailed studies belong to James (1890), Cooley (1902); Mead (1934), Aricak (1999). Although self-studies, which started in the 189os under the leadership of William James, showed important developments, it is seen that there is not yet a definite concept unity on the terminology and functional definitions of the concept (Korkmaz, 1996). James (1890) described the self as a simultaneous development of "self", which was defined by physical, social, emotional and mental qualifications, and the "self", which includes the functions of perception, thinking and remembering. Since the subject of science should be object nature, then the self that can be the subject of psychology is the known ego field. Cooley (1902) took a different approach to the self. According to him, people develop a consciousness about how other people see them during the development process. However, these images may not be accurate in certain respects; but it is still important for the individual (cited in Aricak, 1999). Cooley's "mirror self metaphor" is very important in terms of revealing the selfconcept as a product of social interaction. According to the mirror self metaphor, the self-concept is formed as a reflection of the reactions of others. The self-perception of the individual is also formed by feelings such as pride or humiliation regarding these judgments (cited in Armutlu, 2008).

Self-concept theory and research is an emerging concept in the fields of psychology, sociology, and psychoanalysis. In order to minimize the impact of these overloads, training is being done against the factors that cause it to be (Sallayici et al., 2018). Self-concept is used as a self-reference, the integrity of feelings and thoughts about himself. For psychoanalysis, self-concept is a source of psychological stress and conflict (Rosenberg, 1990). Self-concept is defined as the awareness of the mental and physical attributes of a person, together with what they feel about their qualities.

Self-esteem is a different concept from the self-

*Corresponding Author: zaripheo2@gmail.com 
concept. It is the constellation of expressions that a person uses to describe himself. Self-esteem is an evaluation of the information included in the self-concept and the child's emotion about all these components (Pope et al., 1988). Self-esteem is the degree to which a person is valuable in the world. The child who answers the questions " Do teachers respect my opinions? What talents and traits do I have that are important to others? etc." positively develops a sense of self-confidence, worthiness, and self-worth (Lingren, 1991). James (1890) argued that self-esteem is determined by the degree to which a person is at peace with himself, as well as the ratio of his accomplishments to his desires. Accordingly, only a person whose desires and goals are realistic will be happy because he will see himself valuable (Bruno, 1996). Rosenberg (1965) defined self-esteem as an individual's positive and negative attitude towards himself.

Coopersmith (1967) defined self-esteem as an evaluation of the individual's self-esteem and explains it as an expression of an individual's belief in his own competence, importance, success and values, and his attitude of self-affirmation or disapproval. According to him, self-esteem shows stability under normal conditions, but he stated that self-esteem can vary according to different areas of life, gender, age and other definition conditions (Cited in Üre, 2007). Derlega \& Janda (1982) stated that the term self-esteem is more specific than the self-concept. Self-esteem generally includes how we think about ourselves, whether positive or negative(cited in Kaya and Saçkes, 2004). According to the explanations above, it is seen that the concepts of self and self-esteem are different.

Self-efficacy was first introduced as a concept with Bandura's Social Learning Theory which was started to be used with name "Psychological Repetition-Self-Efficacy: Towards Unifying Behavior Change Theory" (Synder and Lopez, 2005). According to Bandura (1977), self-efficacy perception is the state of determining how a person motivates himself, what he feels and how he should behave Mastering the skills also allows the individual to achieve success. Self-efficacy is a variable concept, not a definite or fixed concept (Baron \& Byrne, 200o). Self-efficacy in an individual consists of sub-skills that are able to handle changing conditions and operate in an interrelated way. Individuals who do not believe in themselves will believe that they are inadequate even when opportunities are presented to them (Wood \& Bandura, 1989). Self-efficacy can be defined as individuals' own personal judgments about their capacity to carry out their behaviour and activities. Self-efficacy beliefs according to Bandura; It affects the choice of behaviours, the ability to withstand the difficulties experienced, the level of striving for activity and the performance shown in the activity. If individuals believe that they have the interest, ability and power of management required to perform a task, they exhibit the necessary behaviours in a more willing and determined manner (Zimmerman, 200o). Coleman \& Karraker (1997) defined self-efficacy as the belief of one's own ability to be successful in performance.

Maddux (2002) defined self-efficacy as the beliefs of an individual to produce something in line with their demands and wishes. According to Senemoğlu (1998), self-efficacy is the judgment and belief about oneself about to what extent an individual will be successful in overcoming difficult situations that they may encounter in the future. This thought is the determinant of individuals' displaying certain behaviours and their efforts to display behaviours despite the daunting situations that may arise while performing these behaviours (Synder \& Lopez, 2005). As a result, there is an intense relationship between self-efficacy and the achievement level of the individual.

The aim of this study was an examination of selfefficacy and self-esteem levels of sports club members in terms of membership history and gender. It is thought that thanks to the findings to be obtained in this research, it would guide researchers in future studies regarding sports club members. It will help sports clubs to make a more accurate assessment in member selection. It is thought that this research can meet the needs in the areas that are lacking before society.

\section{Materials and Methods:}

This research is a quantitative and relational screening model designed to determine the relationship between selfesteem and self-efficacy levels of sports club members. Relational screening model is considered as a study aiming to determine the existence and level of co-change between two or more variables in a current situation in the past or present (Karasar, 2015).

The sample of the study consisted of 246 members of the sports club in the Mediterranean region. Total female were 117 (48\%); Male 129 (52\%). The easily available sampling method was used in the sample selection. The mean age of the sports club members participating in the study was $40.46 \pm 8.23$. In addition, $105(43 \%)$ sports club members who participated in the study were members of the sports club for $0-3$ years and 141 (57\%) sports club members were sports club members for more than 3 years.

During the data collection process, the necessary explanations were made to the participants by the researcher for the purpose, scope of the research and to protect the confidentiality of the information to be obtained. Only volunteer Sports Club members were included in the study. In addition, the personal information form created by the researcher was used to determine the demographic information of the participants.

Data Collection Tools

Stanley Coopersmith Self-Esteem Scale: in calculating the self-esteem scores of the Sports Club members, Self- 
Esteem Scale which was developed by Stanley Coopersmith and adapted into Turkish by Turan \& Tufan (1987), was used who found the test-retest reliability of the scale as 0.65 and 0.76 in their studies conducted with one year interval. The scale consists of 25 items that can be marked as "like me" or "not like me". These items include expressions about the person's perspective on life, family relationships, social relationships and endurance. Scores vary between o and 10o. Evaluation was made according to the self-esteem being lower and higher than average. A score below the average indicates low self-esteem, and a higher than average score indicates high self-esteem.

Self-Efficacy Scale: the scale used in the research is the Self Efficacy Scale (SES) developed by Riggs et al. (1994). The Self-Efficacy Scale was developed to measure individuals' belief in their own capacities. The scale, adapted to Turkish by Öcel (2002), consists of 10 items. Participants evaluate to what extent they agree with the statements in the items on a 5-Likert Type scale, and a single qualification score is obtained by adding the numerical values marked for the items. The internal consistency coefficient calculated by Riggs et al. (1994) and reported by other researchers was expressed as .8o.In order to examine the construct validity of the Turkish form of the scale, it was decided to use factor analysis and the items with a factor range of at least 30 in the scale. Analysis results showed that the scale has a single factor structure and the factor range values of the items varied between .32 and. 85 , that is, the factor range values of all items were greater than. Based on these findings, it was concluded that the Turkish form of the scale was sufficient in terms of construct validity. On the other hand, the internal consistency coefficient of the scale was calculated at as.61. Although this value is not as high as expected, it was found to be sufficient (Öcel, 2002).

Data Analysis: in the data analysis in the study, normality test was performed first. Since the number of the sample is greater than 50, Kolmogorov-Smirnov Normality Test was examined. Kolmogorov-Smirnov Normality Test result showed normal distribution because the significance value was greater than .05 ( $>$ >05). Then, in order to determine whether the self-esteem and self-efficacy levels of the participants in the study differed in terms of gender and membership duration, an independent sample t-test and Pearson correlation analysis were performed to determine the relationship between them. SPSS package program was used to analyze the data obtained in the study.

\section{Results:}

Table-1: T-test results conducted to determine whether selfesteem scale scores differ as per the gender variable

\begin{tabular}{lllllrll}
\hline Gender & $\mathrm{N}$ & $x$ & $\mathrm{SD}$ & $\mathrm{Sh}_{\mathrm{x}}$ & $\mathrm{t}$ test-> T & $\mathrm{Sd}$ & $\mathrm{P}$ \\
\hline Female & 117 & 75.19 & 5.56 & 0.65 & 1.24 & 244 & 0.16 \\
Male & 129 & 74.22 & 6.72 & 0.81 & & & \\
\hline
\end{tabular}

In terms of gender, there was no statistically significant difference(Table-1).

Table-2: T-test results conducted to determine whether scores of general self-efficacy scale differ by gender variable

\begin{tabular}{llllllll}
\hline Gender & $\mathrm{N}$ & $x$ & $\mathrm{SD}$ & $\mathrm{Sh}_{\mathrm{x}}$ & ttest-> T & $\mathrm{Sd}$ & $\mathrm{P}$ \\
\hline Female & 117 & 3.95 & 0.11 & 1.26 & 1.43 & 244 & 0.19 \\
Male & 129 & 3.78 & 1.24 & 1.42 & & & \\
\hline
\end{tabular}

In terms of the self-efficacy average scores of sports club members, there was no statistically significant difference (Table-2).

Table-3: T-test results conducted to determine whether selfesteem scale scores differentiated according to the date of membership variable

\begin{tabular}{lllllrll}
\hline Duration & $\mathrm{N}$ & $x$ & $\mathrm{SD}$ & $\mathrm{Sh}_{\mathrm{x}}$ & t test-> T & $\mathrm{Sd}$ & $\mathrm{P}$ \\
\hline o-3 years & 105 & 74.19 & 4.23 & 0.61 & 7.43 & 244 & 0.00 \\
>3 years & 141 & 54.22 & 8.11 & 0.86 & & & \\
\hline
\end{tabular}

In terms of the self-esteem mean scores of sports club members there was a statistically significant difference $\left(\right.$ Table$\left.^{-3}\right)$.

Table-4: T-test results conducted to determine whether the
scores of the general self-efficacy scale differentiated
according to the date of membership variable
\begin{tabular}{lllllllll}
\hline Duration & $\mathrm{N}$ & $x$ & $\mathrm{SD}$ & $\mathrm{Sh}_{\mathrm{x}}$ & t test-> T & $\mathrm{Sd}$ & $\mathrm{P}$ \\
\hline 0-3 year & 105 & 3.81 & 0.18 & 1.20 & 9.12 & 244 & 0.00 \\
>3 years & 141 & 2.66 & 1.20 & 1.39 & & &
\end{tabular}

There was a statistically significant difference in the self-efficacy mean scores of sports club members in terms of membership date. The mean score of $\mathrm{o}^{-} 3$ year sports club members was higher than the mean score of the participants who have been members of the sports club for $>_{3}$ years $\left(\right.$ Table $\left.^{-} 4\right)$.

\section{Discussion:}

When the self-esteem mean scores of sports club members were examined in terms of gender, there was no statistically significant difference was seen. Özşaker et al. (2011) included 344 students in their study to examine the relationship between pre-service physical education teachers' beliefs in knowing and learning and their selfesteem. They reported the level of self-esteem did not differ statistically in terms of gender which support our research. Parmaksiz (2011) supports our research where a significant difference according to self-esteem levels and some demographic variables was evidenced. Güngör's (1989) observed no relationship between self-esteem and gender, Cerit-Aksoy (1992) examined self-esteem and some influencing variables where gender and self-esteem were found to be related. These findings do not support our research. Block \& Robins (1993) observed that boys 'selfesteem increased and girls' self-esteem decreased. The personal characteristics associated with high self-esteem were the same in both genders. 
When the self-esteem mean scores of sports club members were examined in terms of membership history, there was a statistically significant difference. Yerebakan (2007) found no significant difference between the groups according to the variables of gender and years of service between the selfesteem scores of the administrators, a significant difference was found between the groups according to the variable of years of service. This research does not support our research. Cardinali \& D'Allura (2001) found a significant difference between years of service and self-esteem. It has been reported that Erikçi (2005) has an increase in self-esteem score means. Yegül (1999) stated that the feeling of satisfaction that comes with success can cause individuals to perceive themselves adequately by creating positive thoughts.

In our study, when the self-efficacy mean scores of sports club members were examined there was no statistically significant difference. When we look at the studies about self-efficacy in our country and in the world, the self-efficacy belief levels of professional candidates in their own fields and the teaching profession, students and hospital employees' self-efficacy beliefs are based on their gender, grade levels, academic achievement, type of high school and department they study, etc. It has been observed in some of the self-efficacy study conducted in Turkey have already demonstrated to be related to gender and years of service. It was explained in the research results that there were differences in self-efficacy. In line with this thought, self-efficacy perception creates a significant difference (Çakıroğlu et al., 2002; Gerçek et al., 2006).

Telef \& Karaca (2011) examined whether self-efficacy differs according to demographic variables where significant difference according to gender was found. Uysal \& Bingöl (2014) found that self-efficacy varies according to gender. Doğan et al. (2015) could not find a significant difference between general self-efficacy and gender. Bandura et al. (2001) stated that self-efficacy perception does not differ in terms of gender. Elizabeth et al. (2004) found that gender has no significant effect on self-efficacy and self-esteem. Netz \& Raviv (2004) found the level of selfefficacy differed in terms of gender and is higher in men. Toros et al. (2018) reported that obese female students with high self-efficacy perception could be aware of their abilities and therefore could trust their abilities. In our study, a statistically significant difference was found when the selfefficacy mean scores of sports club members were examined in terms of membership history. According to Bandura (1986) self-efficacy beliefs are influenced by experiences and environmental models, so it affects students' selfefficacy beliefs with success. For example, individuals with high self-efficacy beliefs approach learning activities, make a great effort, use more effective strategies by striving for a long time in the face of difficulties, and show higher performance than others (Eggen \& Kauchak, 1999).
Bandura (1986) stated the perception of strong efficacy developed over time as a result of successful experiences, and once formed, it gained a stable quality and was not affected by occasional failures. Experiences, where success is attributed to luck and support from others, may not contribute positively to self-efficacy. Judgments obtained indirectly were not as effective as those obtained from individual experiences. As per Bandura (1997) the effect of indirect experience on self-efficacy was directly proportional to the similarity of the observed model to the observer and the observed event to the event or area that develops self-efficacy.

Considering the findings obtained in this study, it differs with the gender of sports club members and the date of membership, and their level of self-esteem and selfefficacy. Studies on this subject should be carried out by considering the data directly related to the experiment. It can be suggested that researchers' research on the same subjects should be handled in a more comprehensive and versatile way. Since research on gender and membership history is insufficient, researchers should look at the different demographic characteristics of both women and men in future studies. Examining the quantity and quality differences in this area will contribute to the field.

\section{References:}

Aricak, O.T. (1999): Grupla Psikolojik Danışma Yoluyla Benlik ve Mesleki Benlik Saygısının Geliştirilmesi. Unpublished Doctoral Thesis, MarmaraUniversity, Educational Sciences Institute.

Armutlu, C. (2008): Sembolik Tüketim: Benlik İmajı Uyumu Üzerine Bir Araștırma. Unpublished Doctoral Thesis, Gazi University, Social Sciences Institute, Ankara.

Bandura, A. (1977): Self-efficacy: Toward a Unifying Theory of Behavioral Change. Psychol. Rev., 84(2):191-215.

Bandura, A. (1986): Social foundation of thought and action: A social cognitive theory. Englewood Cliffs, NJ: Prentice Hall. Pub. by: American Psychological Association.

Bandura, A. (1997): Self-efficacy in changing societies (pp. 1-45). In Bandura, A. (Ed.) Exercise of Personal and Collective Efficacy in Changing Societies. Pub. by: Cambridge University Pres., New York.

Bandura, A. (2001): Social Cognitive Theory. Annual Agentive Perspective. Ann. Rev. Psychol., 52:1-26.

Baron, R.A., Branscombe, N.R. \& Byrne, D.R. (2000): Social Psychology. Pub. by: Pearson, Australia

Block, J. \& Robins, R.W. (1993): A longitudinal study of consistency and change in self-esteem from early adolescence to early adulthood. Child Develop., 64:909-923.

Cardinali, G. \& D'Allura, T. (2001): Parenting styles and selfesteem: A study of young adults with visual impairments. I. Vis. Impairm. Blind., 95(5):261-271.

Cerit Aksoy, A. (1992): Lise son sınıf öğrencilerinin özsaygı ve denetim odağını etkileyen bazı değișkenlerin incelenmesi (Yayınlanmamıș Doktora Tezi). Hacettepe Üniversitesi, Sağlık Bilimleri Enstitüsü, Ankara. 


\section{ORIGINAL ARTICLE}

Coeman, P.K. \& Karraker, K.H. (1997): Self-eficacy and parenting quality; findings and future applications. Develop. Rev., $18(1): 47-85$.

Cooley, C.H. (1902): Human Nature and the Social Order. Pub. by: Scribner, New York.

Coopersmith, S. (1967): The Antecedents of Self-Esteem. Pub. by: Freeman, San Francisco, CA.

Çakı roğlu, J., Özkan, Ö., \& Tekkaya, C. (2002): Fen bilgisi aday ögretmenlerin fen kavramlarını anlama düzeyleri, fen öğretimine yönelik tutum ve öz-yeterlik inançları. V. Fen ve Matematik Kongresi Bildiriler Kitabı içinde (ss. 1300-1304). Pub. by: Devlet Kitapları Müdürlüğü Basımevi, Ankara.

Derlega, V.J. \& Janda, L.H. (1986): Personal adjustment: the psychology of everyday life. Pub. by: Scott Foresman \& Company.

Doğan, B.G., Laçin, E. \& Tutal, N. (2015): Predicatives of the workers' burnout level: Life satisfaction and social support. Procedia-Soc. Behav. Sci., 191:1801-1806.

Eggen, P. \& Kauchak, D. (1999): Educational Psychology. (Fourth Ed.). Pub. by: Printice-Hall, Inc., New Jersey.

Erikçi, M. (2005): Ana-Baba yoksunluğunun 9-15 yaş grubu çocuklarının benlik kavramı üzerindeki etkilerinin çeşitli değişkenler açısından incelenmesi. Yayınlanmamış Yüksek Lisans Tezi, Selçuk Üniversitesi Sosyal Bilimler Enstitüsü, Konya.

Gerçek, C., Yilmaz, M., Köseoğlu, P., \& Soran, H. (2006): Biyoloji eğitimi öğretmen adaylarının öğretiminde öz-yeterlilik inançları. Ankara Üniversitesi Eğitim Bilimleri Fakültesi Dergisi, 39(1):57-73.

Güngör, A. (1989): Lise Öğrencilerinin Özsaygı Düzeylerini Etkileyen Etmenler. Yayınlanmamış Doktora Tezi, Hacettepe Üniversitesi Ankara.

James , W. (1890): Principal of Psychology. Pub by: Holt, New York.

Karasar, N. (2015): Araștırmalarda Rapor Hazırlama (19. baskı). Pub. by: Nobel Akademik Yayincilik, Ankara.

Kaya, A. \& Saçkes, M. (2017): Benlik saygısı geliștirme programinin ilköğretim 8. sinif öğrencilerinin benlik saygısı düzeylerine etkisi. Pub. by: Pegem Atıf İndeksi, 1-39.

Lingren, H.G. (1991): Self-esteem in children. Honolulu (HI): University of Hawaii. 3p. (Children and Family; CF-12).

Maddux, J. E. (2002): Self-efficacy: The Power of Believing You Can, 277-287. In, Shane J. Lopez and C.R. Snyder (ed): The Oxford Handbook of Positive Psychology (2nd edn). Pub. by: Oxford Press Online.

Mead, G.H. (1934): Mind, Self and Society (Vol. 111). University of Chicago Press.: Chicago.

Netz, Y. \& Raviv, S. (2004): Age differences in motivational orientation toward physical activity: An application of Social-Cognitive theory. J. Psychol., 138(1):35-48.

Öcel, H. (2002): Takım Sporu Yapan Oyuncularda Kolektif Yeterlik Öz-yeterlik ve Sargınlık ile Basarı Algı ve Beklentileri Arasındaki İliskiler, HÜ. Yayınlanmamıș Yüksek Lisans Tezi, Ankara.

Özşaker, M., Canpolat, M. \& Yildiz, L. (2011). Beden eğitimi öğretmen adaylarının epistemolojik inançları ve benlik saygıları arasındaki ilişki. Niğde Üniversitesi Beden Eğitimi ve Spor Bilimleri Dergisi, 5(2):155-164.
Ambient Science, 2020: Vol. 07(Sp1); 366-370 DOI:10.21276/ambi.2020.07.sp1.oa49

Parmaksız, I. (2011): Öğretmen adaylarinin benlik saygisi düzeylerine göre iyimserlik ve stresle başaçikma tutumlarinin incelenmesi (Doctoral dissertation, Selçuk Üniversitesi Eğitim Bilimleri Enstitüsü).

Pope, A.W., McHale, S.M., \& Craighead, W.E. (1988). Self-esteem Enhancement with Children and Adolescents. Pub. by: Pergamon Press.

Riggs, M.L., Warka, J., Babasa, B., Betancourt, R. \& Hooker, S. (1994): Development and validation of self-efficacy and outcome expectancy scales for job-related applications. $\underline{E d u}$. Psychol. Measur., 54(3):793-802

Rosenberg, M. (1965): Society and The Adolescent Self-İmage. Pub. by: Princeton University Press, New Jersey.

Rosenberg, M. \& Turner, R.H. (1990): The Self-Concept: Social Product and Social Force, Social Psychology. Pub. by: Transaction Publishers, New Brunswick.

Sallayici, M., Eroglu Kolayis, İ., Kesilmis, İ., \& Kesilmis, M.M. (2018): Examination of Athletes' Anxiety, Motivation, Imagination Value in Competitions with Different Severity Level. Asian J. Edu. Train., 4(1):9-12.

Senemoğlu, N. (1998): Gelişim Öğrenme ve Öğretim. Kuramdan Uygulamaya. Pub. by: Yargı Yayınları, Ankara.

Snyder, C.R. \& Lopez, S.J. (2002): Handbook of Positive Psychology. Pub. by: Oxford University Press, New York.

Telef, B. \& Karaca, R. (2011): Ergenlerin öz-yeterliklerinin ve psikolojik semptomlarının incelenmesi/Adolescents' selfefficacy and psychological symptoms' investigation. Mustafa Kemal Üniversitesi Sosyal Bilimler Enstitüsü Dergisi, 8(16):499-518.

Toros, T., Kesilmiș, İ., \& Başhan, İ. (2018): Relationship between self-efficacy and life satisfaction according to exercise participation in obese female university students. L. Human Sci., 15(4):1847-1853.

Turan, N. \& Tufan, B. (1987): Coopersmith benlik saygısı envanteri'nin (SEI) geçerlik-güvenirlik çalıșması. In: 23. Ulusal Psikiyatri ve Nörolojik Bilimler Kongresi. İstanbul-Türkiye.

Üre, Ö. (2007): Üniversite öğrencilerinin karar vermede özsaygı, karar verme ve stresle baĢa çı kma stillerinin benlik saygısı ve bazı değiG̣kenler açisindan incelenmesi. Yayinlanmamiş Yükseklisans Tezi.

Uysal, R. \& Yılmaz-Bingöl, T. (2014): Ergenlerde risk alma davranışının öz-yeterlik ve farkli değişkenler açisindan incelenmesi. Akademik Sosyal Araștırmalar Dergisi, 2(8):573-582.

Wood, R. \& Bandura, A. (1989): Social cognitive theory of organizational management. Acad. Manag. Rev., 14(3):361-384.

Yegül, I.B. (1999): Liseli Erkek Sporcular ile Sporcu Olmayan Bireylerin Benlik Saygısı ve Atletik Yeterlik Puanlarının Karşılaștırılması. Sağlık Bilimleri Enstitüsü. Yüksek Lisans Tezi, Pub. by: Hacettepe Üniversitesi, Ankara.

Yerebakan, H.B. (2007): Resmi ilköğretim okullarında görevyapan eğitim yöneticilerinin benlik saygısı ve denetim odağı düzeyleri arasındaki ilişkinin incelenmesi. Yayımlanmamıș Yüksek Lisans Tezi, Yeditepe Üniversitesi Sosyal Bilimler Enstitüsü, İstanbul:Türkiye.

Zimmerman, B.J. (200o): Self-efficacy: An essential motive to learn. Contemp. Edu. Psychol., 25(1):82-91. 